\title{
FUZZY MULTICRITERIA FOR DETERMINING REASONABLE ADJUSTMENT IN HOUSING
}

\author{
Luis DELGADO MÉNDEZ ${ }^{1 *}$, Consuelo DEL MORAL ÁVILA ${ }^{1}$, \\ María José DEL MORAL ÁVILA², Juan Miguel TAPIA GARCÍA ${ }^{3}$, \\ Ignacio VALVERDE PALACIOS ${ }^{4}$, Ignacio VALVERDE ESPINOSA ${ }^{4}$ \\ ${ }^{1}$ Architectonic Constructions Department, Architecture College, University of Granada, \\ Campo del Príncipe, s/n, 18071, Granada, Spain \\ ${ }^{2}$ Statistics and Operational Research Department, University of Granada, \\ Avenida Fuentenueva, s/n, 18071, Granada, Spain \\ ${ }^{3}$ Quantitative Methods for Economics and Business Department, University of Granada, \\ Campus de Cartuja, 18071, Granada, Spain \\ ${ }^{4}$ Architectonic Constructions Department, Edification College, University of Granada, \\ Avda. Fuentenueva, s/n, 18071, Granada, Spain
}

Received 23 July 2017; accepted 14 October 2018

\begin{abstract}
Legislative initiatives regarding universal accessibility promote the elimination of architectural barriers. This is a positive measure as it aims to ensure equal rights and opportunities for disabled people, in accordance with the Convention on the Rights of Persons with Disabilities (United Nations, 2006). One of the challenges facing society today is the determination of reasonable accommodation, a concept that encompasses those necessary modifications and adjustments which do not impose a disproportionate burden. For this purpose, technical, economic and social aspects shall be taken into consideration, as required by legislation. This paper proposes reasonable accommodation in residential buildings, taking into account the different options for its attainment, by applying a multi-criteria analysis based on a wide range of objective indicators of three types: technical, social and economic. This proposal was one of the objectives of the $\mathrm{R}+\mathrm{D}+\mathrm{i}$ Project called "VIVable-From accessible housing to sustainable housing: The essence of reasonable accommodation". From VIVable, the fuzzy multi-criteria assessment method for determining reasonable accommodation may be totally extrapolated to other uses. At the same time, the proposed method may also be extrapolated to other countries where basic requirements for universal accessibility in buildings and equal rights of persons with disabilities are standardized.
\end{abstract}

Keywords: fuzzy multi-criteria analysis, reasonable accommodation, accessibility, accessible housing, sustainable housing, elimination of architectural barriers.

JEL Classification: C63, H53, R21.

*Corresponding author. E-mail: ldelgado@ugr.es

This is an Open Access article distributed under the terms of the Creative Commons Attribution License (http://creativecommons. org/licenses/by/4.0/), which permits unrestricted use, distribution, and reproduction in any medium, provided the original author and source are credited. 


\section{Introduction}

The concept of reasonable accommodation in terms of universal accessibility arises initially within the field of work and with regards to the adaptation of the work place for a person with disabilities. This is included in the Directive 2000/78 / EC (Council of Europe, 2000), where the term is defined as being those measures to be carried out by employers to ensure compliance with the principle of equal treatment, taking into account the needs and specific situation of each person with disabilities, provided that the accommodation does not suppose an excessive burden for the employer.

In Spain, the concept of reasonable accommodation was regulated for the first time within the law Act on Equal Opportunities, Non-Discrimination and Universal Accessibility (Ley 51, 2003), which is currently regulated in the Consolidated Text of the General Law on the Rights of Persons with Disabilities and their Social Inclusion (Real Decreto Legislativo 1, 2013).

In this law's second article (art. 2. m), reasonable accommodation is defined as "those necessary and appropriate modifications and adaptations of the physical, social and attitudinal environment to the specific needs of persons with disabilities that do not impose a disproportionate or undue burden, when required in a particular case in an effective and practical manner, to facilitate accessibility and participation and to guarantee persons with disabilities the enjoyment or exercise, on equal terms with others, of all rights".

In order to determine if the accommodation is reasonable, the article 66.2 of the Consolidated Text, established that "the costs of the measure, the discriminatory effects that the nonadoption of these measures has on persons with disabilities, the structure and characteristics of a certain individual, entity or organization that has to put it into practice, and the possibility of obtaining official financing or any other help will be taken into account".

After analyzing reasonable accommodation in these articles, in relation to universal accessibility, this concept is based on four elements that must always be taken into account:

1. The subject to whom it is addressed is the person with disabilities, in order to assure equal treatment with regards to the rest of the population, assuming the disadvantages related to their disabilities (de Oliveira et al., 2014);

2. Various types of measures will be taken against discrimination, including actions that will modify the physical environment, such as reasonable accommodation (de Oliveira et al., 2014; Cocco \& Alonso, 2015);

3. Those responsible for carrying out reasonable accommodation may be individuals, entities or organizations, and the objective is to facilitate the accessibility or participation of disabled persons on equal terms with the rest of the citizens.

4. In order to determine when necessary and appropriate modifications and adaptations of the physical, social and attitudinal environment become a disproportionate or undue burden, several qualitative criteria - which can also be quantified - are set:

- Costs of the measures;

- Discriminatory effects that the non-adoption of these measures may have on the disabled person (de Oliveira et al., 2014);

- Structure and characteristics of the person, entity or organization that must undertake these actions;

- The possibility of obtaining official funding or some kind of support. 
Ultimately, the decision as to whether or not the adaptations of the physical environment in order to fit the needs of persons with disabilities are a disproportionate burden or not must be taken on the basis of a broad and complex analysis which includes all four general criteria (Delgado, del Moral, \& Corredor, 2016; Cocco \& Alonso, 2015).

The Land and Rehabilitation Law (Real Decreto Legislativo 7, 2015) is the only legal text that quantifies disproportionate burden in its art. 2.5, regarding buildings constituted under the system of Horizontal Property: "when the annual cost of the construction work - after deducting public subsidies to which they may be entitled - exceeds twelve ordinary monthly installments of communal expenses". In this type of building, an intervention, that may or may not be considered to be a disproportionate burden, will have an important juridical and social impact. If the measure is considered to be reasonable accommodation, the residents' association has the obligation to carry it out. The measure's impact will be immediate, as it will improve the quality of life of the persons with disabilities living in these buildings.

However, no legislation exists describing the configuration of reasonable accommodation for public or private buildings under Spanish law. This situation has two effects:

- The non-compliance of the basic conditions of accessibility and non-discrimination mentioned in the Consolidated Text (Real Decreto Legislativo 1, 2013) within the required time limit: December the 4th, 2017 in most cases;

- The setting of priorities regarding interventions related to accessibility and non-discrimination measures in Plans and Programs will not take into account the determination of reasonable accommodation with regards to measures for improving accessibility.

This situation implies the non-compliance of the specific needs of persons with disabilities with regards to collective activities in their daily life, at least in the short term.

This article shows the results obtained in a research carried out in the $\mathrm{R}+\mathrm{D}+\mathrm{i}$ project called "VIVable - From affordable housing to sustainable housing: the essence of reasonable accommodation" (Delgado et al., 2015) with reference to a reasonable accommodation proposal for the improvement of accessibility in residential multi-family buildings, or residential buildings under the system of Horizontal Property. This proposal is based on a fuzzy multicriteria evaluation of technical, social and economic criteria (Delgado et al., 2016), using the Scoring method (Mardani, Jusoh, \& Zavadskas, 2015) or linear weighting.

This investigation's main goal is to propose a methodology - still today, non-existent- capable of determining reasonable accommodation in residential buildings. This methodology responds to persons' with disabilities complex reality with regards to the buildings where they carry out an important part of their daily activities. It also responds to the search for an inclusive design capable of promoting the production of spatial qualities and opportunities for diverse use (Heylighen, Van der Linden, \& Van Steenwinkel, 2017). This methodology entails three significant improvements regarding the quality of life of persons with disabilities:

- The improvement of the determination of reasonable accommodation with regards to what is currently established in the Land and Rehabilitation Law (Real Decreto Legislativo 7, 2015), which only takes into account the "cost-solution" economic criteria corresponding to 12 monthly payments of the residents' association regular budget in a multifamily residential building. Other residential and public buildings are not taken into account; 
- Complying with the requirements reflected in the Convention for the Rights of Persons with Disabilities (United Nations, 2006), with regards to the insurance of equal rights and opportunities for these persons;

- The possibility of determining reasonable accommodation in other buildings, given the fact that the proposed methodology allows simple modifications within wide groups of criteria derived from the requirements of the current Spanish legislation, as well as other regulations.

The proposed methodology for determining reasonable accommodation is based on a linear weighting method and a multi-criteria fuzzy logic which must be considered for two reasons:

- The aforementioned complex reality of both persons with disabilities and the residential buildings where they carry out their daily life;

- The use of the AppWeb prototype called SIG-ACCE.

In general, the person who must make a decision regarding a set of possible alternatives as a solution to a particular problem, does not tend to order them under a single criterion, something that would greatly simplify the process. On the contrary, the person does so based on a broad set of criteria as this is more appropriate. This is how the multi-criteria decisional framework arises. There are different approaches to MCDM that have been described in several scientific articles, including ( X. Zhang, H. Zhang, \& Wang, 2017; T. Zhang, Wang, \& H. Zhang, 2018; X. Wang, Peng, \& J. Wang, 2018a; L.Wang, Peng, \& J. Wang, 2018b; Ji, Zhang, \& Wang, 2018).

The best known methods of multi-criteria assessment are: the Linear Weighting method (SCORING), the Hierarchical Analysis Process (AHP) method, the Multi-attribute Utility (MAUT) method and the Relationship of Improvement method. The SCORING method and the AHP method are used more frequently when decisions are made using multi-criteria evaluation techniques that are of a spatial nature, so that they can be implemented using Geographic Information Systems (GIS).

With regards to the project $\mathrm{I}+\mathrm{D}+\mathrm{i}$ VIVable, the chosen method was Scoring, given the fact that its implementation is carried out through an AppWeb prototype under an Accessibility System of Geographical Information called SIG-ACCE. This way, the reasonable accommodation proposal is the result of the decision made by a qualified technician regarding a set of alternatives based on a broad set of criteria derived from the requirements of the Consolidated Text of the General Law on the Rights of Persons with Disabilities and their Social Inclusion (Real Decreto Legislativo 1, 2013). There are three types of criteria that will help meet these requirements:

- Technical criteria: actions which eliminate barriers and improve the accessibility conditions of buildings and their environment;

- Social criteria: the discriminatory effects that the non-adoption of the measures might have, as well as the structure and characteristics of the person or entity that has to put them into practice, must be taken into account;

- Economic criteria: the cost of the measure must be taken into account and evaluated to discern if it proves to be a disproportionate burden; the possibility of obtaining funding or any other aid must be considered (Delgado et al., 2016; Cocco \& Alonso, 2015). 
The article is structured as described below. After the introduction in Section 1, the background information on the use of multi-criteria assessments in decision making processes is described. Section 2 presents the proposed objective and methodology. Section 3 describes the application of the method of linear weighting and fuzzy logic to decision making in accessibility. Sections 4 and 5 present the decision criteria and their quantification. In section 6 the results obtained are discussed. The conclusions are presented in the final section.

\section{Background}

\subsection{The problem of multi-criteria group decision making with linguistic preference relations}

A group decision-making process consists of finding the best option within a set of possibilities. As this process is present in most human activities, its study has become very important in a wide variety of areas. Also in certain cases, the comparison of different types of actions according to their suitability in decision making problems cannot be performed by a single criterion.

In this situation, a multi-criteria decision making problem can be interpreted as a decision making problem in which a set of experts - individuals or decision-makers - try to reach a common solution by expressing their opinions - preferences - about a set of alternatives in the presence of a set of criteria (Pedrycz, Ekel, \& Parreiras, 2011). Fuzzy multi-criteria decision making is one of the most popular problems handled by researchers in current literature (Kahraman, Onar, \& Oztaysi, 2015; Kahraman, Suder, \& Cebi, 2013) and, in particular, there is a significant growth in its use in applications for infrastructure management (Haque, 2016; Oltean-Dumbrava, Watts, \& Miah, 2016; Kabir, Sadiq, \& Tesfamariam, 2014).

The evaluation of infrastructure management can be seen as a multi-criteria decisionmaking problem with various contradictory criteria, and in addition, the vague nature of this evaluation requires a diffuse multi-criteria methodology (Suder \& Kahraman, 2016).

Many problems present quantitative aspects that can be treated by precise numerical values with the help of fuzzy logic theory, in order to obtain an appropriate solution (Guo \& Zhao, 2017; Herrera \& Herrera-Viedma, 2000; Herrera-Viedma, Martínez, Mata, \& Chiclana, 2005; Xu, 2005, 2007; Zadeh, 1975a, 1975b, 1975c). But it is also common to find problems in which it is necessary to use variables classified according to a set of linguistic terms - labels that each expert uses to express his/her opinion about the set of alternatives as a relation of fuzzy linguistic preference (Azcona, 2014; Herrera, Herrera-Viedma, \& Verdegay, 1997).

Usually, in a decision-making problem in a multi-criteria group with linguistic preference relationships we can find a finite set of alternatives $X=\left\{x_{1}, \ldots, x_{m}\right\}(m \geq 2)$ and a finite group of experts $E=\left\{e^{1}, \ldots, e^{r}\right\}(r \geq 1)$ that express their preferences using a fuzzy linguistic preference relationship according to a finite set of criteria $Y=\left\{y_{1}, \ldots, y_{\mathrm{n}}\right\}(n \geq 2)$. In this context, a decision-making problem in a multi-criteria group consists in obtaining a classification of $\mathrm{X}$ based on preferences $p_{i j}^{k}$ expressed by the experts (Morente-Molinera, Kou, González-Crespo, Corchado, \& Herrera-Viedma, 2017; Herrera, Herrera-Viedma, \& Martínez, 2000) where $p_{i j}^{k}$ indicates the preference of the alternative $x_{j}$ for criterion $y_{i}$ expressed by the expert $e^{k}$. 
These preferences are usually presented through a matrix. So, for an expert $e^{k}$, his or her preferences can be manifested as follows:

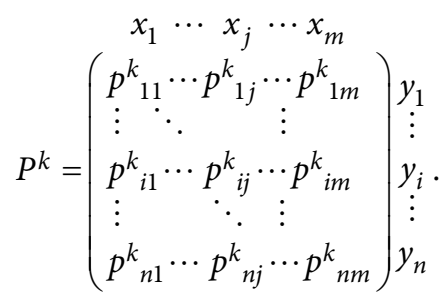

\subsection{Problem solving process}

The solution scheme for the aforementioned problem is the following (Morente-Molinera et al., 2017):

i. Obtaining preferences. The preferences of each expert regarding each of the alternatives according to specific criteria are obtained. In order to obtain these preferences through fuzzy linguistic preference relations it is necessary to use linguistic assessments - linguistic variables - instead of numerical values - numerical variables. A scale of linguistic expressions - a linguistic term set - is thus introduced to express these preferences. Usually, this linguistic term set presents an average and the remaining terms are symmetrically positioned around it. The number of terms constitutes the granularity of the established linguistic term. So, it is necessary to choose the granularity of the linguistic term set, its labels and its semantics. The semantics of elements of the term set are given by fuzzy numbers defined in $[0,1]$ interval using membership functions (Herrera \& Herrera-Viedma, 2000). There are different membership functions to capture the vague nature of these linguistic assessments.

Linear trapezoidal membership functions can be considered adequate to capture the vague nature of these linguistic statements. A linear trapezoidal membership function can be represented by a set of 4 -uplas $\left(a_{i}, b_{i}, a_{i}, b_{i}\right)$. The first two parameters of each 4 -upla indicate the interval in which the membership value is 1.0 -maximum-and the last two indicate the left and right amplitudes of the distribution, respectively. The graphic representation of a membership function of this type can be seen in Figure 1.

The concept of a linear trapezoidal membership function is reflected in the following example. We consider a set of linguistic labels completely ordered and finite, $S=\left\{s_{0}, \ldots, s_{T}\right\}$, with odd cardinality, where each label $s_{i}$ represents a possible value for a real linguistic variable. The set of linguistic labels with their respective associated semantics is the following:

$$
\begin{array}{lll}
s_{0}=\mathrm{N} & \text { None } & (0.0,0.0,0.0,0.6) \\
s_{1}=\mathrm{L} & \text { Low } & (0.7,1.3,0.3,0.3) \\
s_{2}=\mathrm{M} & \text { Medium } & (1.7,2.3,0.3,0.3) \\
s_{3}=\mathrm{H} & \text { High } & (2.7,3.3,0.3,0.3) \\
s_{4}=\mathrm{VH} & \text { Very high } & (4.0,4.0,0.6,0.0)
\end{array}
$$

and its graphic representation is shown in Figure 2. 


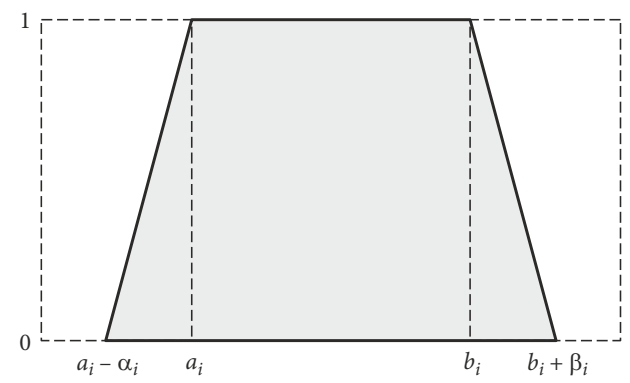

Figure 1. Representation of a linear trapezoidal membership function (source: own development)

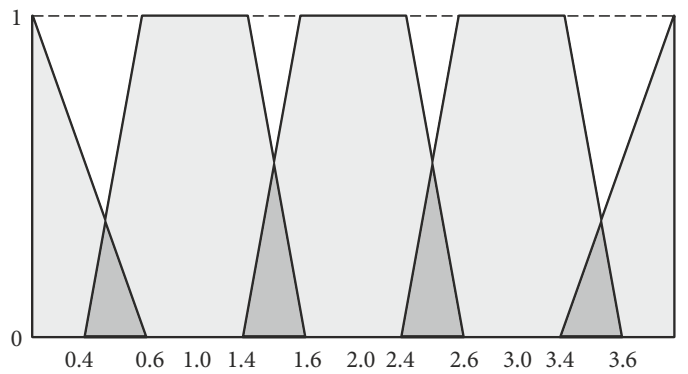

Figure 2. Linguistic term set (source: own development)

Different preference relation representation formats can be found in literature. Recent papers use hesitant preference relations (Liao, Xu, \& Zeng, 2014; Wei, Zhao, \& Tang, 2014; Wang, Zhang, \& Chen, 2014; Zhu \& Xu, 2016) or interval-valued preference relations (Xu, 2004; Yager, 2014) or introduce problems in which attribute values take the form of the interval-valued intuitionistic fuzzy numbers (Xu \& Yager, 2009; Liu, 2014).

ii. Aggregation process. Once the experts have expressed their preferences, this information is combined in a single matrix that represents the preferences of the set of experts. This procedure defines a fuzzy collective linguistic preference relation obtained by the aggregation of all the individual linguistic fuzzy preference relations. At this stage, an important issue is the assignment of the level of importance of the values of each criterion, as the importance of the criteria is usually not the same. A common practice is to allow the experts to decide, but there are other possibilities such as their assignment by higher level experts. Thus, in the aggregation process, the application of a weighting factor to each of the preferences is carried out according to the criteria used. Its calculation is given by:

$$
w_{i} * \phi_{i j}, \quad i=1, \ldots, n ; j=1, \ldots, m,
$$

where $\phi_{i j}=\phi\left(p_{i j}^{1}, \ldots, p_{i j}^{r}\right)$ and $\phi$ is an aggregation operator; $w_{i}$ is a weighting factor. Different linguistic aggregation operators have been proposed (Herrera \& Herrera-Viedma, 2000).

iii. Selection process. Finally, once the collective preference matrix has been obtained, a selection process is applied to obtain a final classification about the alternatives. This process transforms the collective information on alternatives into a global classification, thus making 
it possible to choose the solution set. A method commonly used is the application of a selection function (Herrera \& Herrera-Viedma, 2000). The choice degree by means of dominance (QGDD, quantifier-guided dominance degree) applied over the preference relation allows us to obtain a final classification of the alternatives. For an alternative xi, the operator QGDD (Morente-Molinera et al., 2017) can be calculated via the collective preferences matrix as follows:

$$
Q G D D_{j}=\sum_{i=1}^{n} w_{i}^{*} \phi_{i j} .
$$

The classification of the alternatives is obtained as follows (J. Tapia, Del Moral, C. Tapia, Martínez, \& Amor, 2012; Tapia, Del Moral, Martínez, \& Herrera-Viedma, 2012):

$$
\text { If } Q G D D_{k}>Q G D D_{l} \text { then } x_{k} \text { is preferable to } x_{l} \text {. }
$$

An outline of this process is shown in Figure 3.

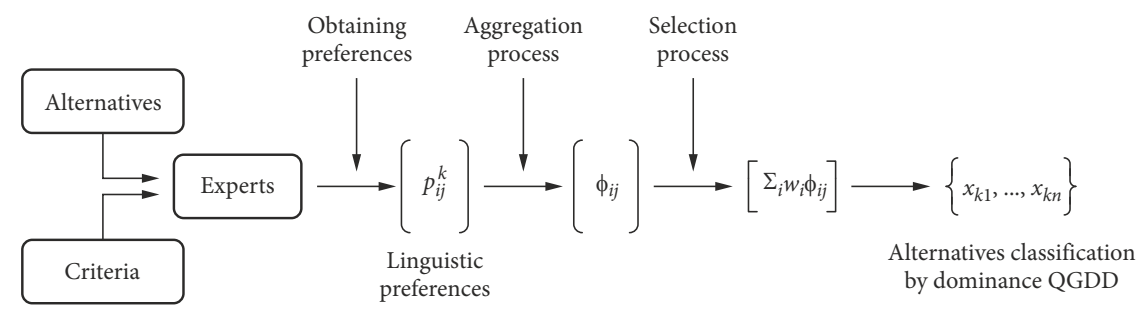

Figure 3. Multi-criteria linguistic modelling scheme (source: own development)

\section{Objective and proposed methodology}

The main objective of this article is to formulate a proposal for evaluating different alternatives that can be undertaken in a multi-family residential building to improve its accessibility conditions.

This general objective has three specific goals:

1. The establishment of objective criteria adjusted to the different areas established in the legislation (Real Decreto Legislativo 1, 2013): technical, social and economic areas.

2. To carry out a comparison between the possible alternatives for improving accessibility conditions, based on the established objective criteria.

3. To determine the consideration of reasonable accommodation for each of the possible alternatives.

The methodology intended to achieve the specific objectives includes the sections indicated below, included in Figure 4.

- The determination of the fuzzy criteria to be considered in the decision making process. These criteria are the variables that allow evaluation of the degree of approach to, or the achievement of, the objective. The most relevant characteristics must be taken into account by the decision makers in order to evaluate the ideal alternative.

- To assign weighting to each of the criteria. The criteria may have quantitative and qualitative aspects. When the aspects are quantitative, their weighting is immediate, 


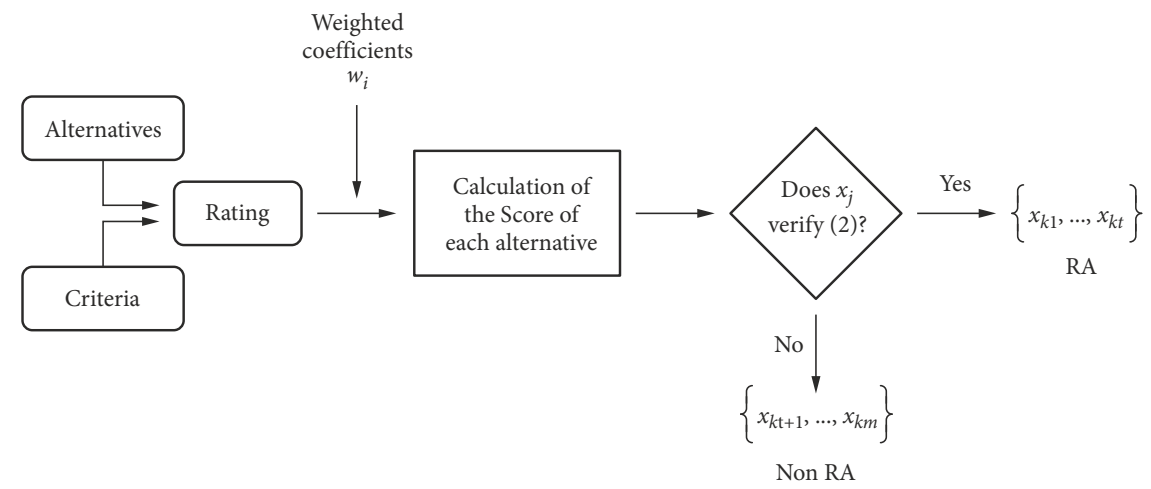

Figure 4. Proposed methodology (source: own development)

thus defining the limits of each scoring section. However, certain qualitative aspects are difficult to score when dealing with imprecise propositions such as: "this man is quite short", "I am very close", "I have taken a long time" (Azcona, 2014). In these cases, the mechanisms of fuzzy logic developed by Zadeh in the 1960s will be used. Through a rating scale they become indicators that represent reality in a quantitative, simple and direct way.

- The Score Calculation of each alternative action for improving the accessibility of the building and each part of it. The obtained score permits the determination of whether or not it is considered as reasonable accommodation, RA.

- The classification of alternatives according to the Score. The score reflects the degree of adaptation to the established criteria.

In the VIVable $\mathrm{R}+\mathrm{D}+\mathrm{I}$ project, the SIG-ACCE web App prototype permits the computerized use of the proposed linear and fuzzy logic methodologies.

\section{Linear weighted method and fuzzy logic applied to decision making in accessibility}

As Sixto Ríos clearly states, "in economic, social, political reality [...], complex situations, where one has to choose between several possible courses of action in order to follow the optimum one, frequently arise. For this decision making, the experts' experience, common sense or intuition are not enough, as multiple criteria, several decision-makers, uncertainty, different stages, etc. often come into play”. (Ríos, S. Ríos-Insúa, \& M. Ríos-Insúa, 1989).

In its most basic form, a decision-making process can be understood as the choice of the "best" choice out of all the "possible" choices. Depending on the definition of what is the best and what is possible, we will face different decisional situations. With regards to a multi-criteria decision, despite the fact that the consequences for a particular decision are perfectly determined, what is not defined so clearly is which is the best, as there are various objectives in conflict with one another (Vitoriano, 2007).

In this case - decision making with regards to the accessibility of residential housing buildings - we find ourselves with some specific characteristics. There may only be one deci- 
sion maker in the case of single-family homes, or a group of them in the case of dwellings under the system of Horizontal Property. In this second case, they must seek consensus for the adoption of a solution that best reflects their interests. In the proposal included in this article, we assume that the experts' preferences relative to $X$ are described by a relation of fuzzy preferences for each criterion, which we will call $L$, and which can be represented as:

$$
L \subset X \times Y,
$$

whose membership function will be

$$
L \subset X \times Y \rightarrow S
$$

For the expert $E, L\left(x_{j}, y_{i}\right)=p_{i j}$ denotes the degree of fuzzy linguistic preference taken from a set of linguistic labels $S$ of the alternative $x_{j}$ with respect to the criterion $y_{i}$ with $s_{o} \leq$ $p_{i j} \leq s_{T}$. Also, motivated by the order induced by the set $\mathrm{S}$, we can define a natural function:

$$
s: S \rightarrow \mathbb{N},
$$

through the assignment $s\left(p_{i j}\right)=a$ if $p_{i j}=s_{a}$ - integer valuation.

The decision process (Garcia-Cascales, Lamata, \& Ruiz-Merino, 2009) includes the sentences reflected in Figure 5.

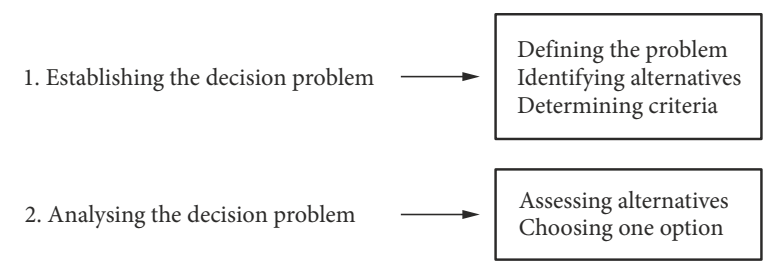

Figure 5. Decision process phases (source: own development)

This is a method based on value function, which consists of constructing a function that associates a real number with each of the possible alternatives. This number reflects the value or utility that each alternative has for the decision maker (Guo \& Zhao, 2017; Garcia-Cascales et al., 2009). The main difficulty of this method is the determination of this value function, but once obtained, the problem of deciding which is the best of the alternatives is reduced to obtaining the maximum of all the calculated values.

The linear weighting method establishes that the function to obtain the score of each alternative, in accordance with (1), has the following expression:

$$
S_{j}=\sum_{i=1}^{n} w_{i}{ }^{*} r_{i j} \text {, }
$$

where: $S_{j}$ is the score obtained by alternative $x_{j},(j=1, \ldots, m) ; r_{i j}$ es el rating obtained by alternative $x_{j},(j=1, \ldots, m)$, according to criterion $y_{i},(i=1, \ldots, n) ; w_{i}$ is the weighting established for each criterion $y_{i},(i=1, \ldots, n)$.

In the VIVable $\mathrm{R}+\mathrm{D}+\mathrm{i}$ project, the use of the linear weighting method is proposed and, based on the legal framework already analysed, three types of criteria are established in order to determine whether an action is considered reasonable accommodation (Cocco \& Alonso, 2015; del Moral \& Delgado, 2010): 
- Technical criteria: actions that eliminate barriers and improve the accessibility conditions of buildings and their environment.

- Social criteria: the discriminatory effects that the non-adoption of the measures might have, as well as the characteristics of the person or the characteristics and structure of the entity that has to put them into practice, must be taken into account.

- Economic criteria: the cost of the measures must be taken into account and evaluated in case they represent a disproportionate burden; the possibility of obtaining funding or any other aid must be considered (Delgado et al., 2016; Cocco \& Alonso, 2015).

Within the VIVable $\mathrm{R}+\mathrm{D}+\mathrm{i}$ project, it is proposed that the rating or qualification obtained for each alternative be assigned according to a homogeneous scale for all the criteria ranging from 0 to 4 , with the valuation collected in the Table 1 . It is considered that this scale is sufficient to establish the differences in value that can be noted between the different alternatives (Guo \& Zhao, 2017).

Table 1. Rating scale (source: own development)

\begin{tabular}{|l|c|}
\hline \multicolumn{1}{|c|}{ Linguistic labels } & Rating scale \\
\hline The criterion could not be taken into account and, therefore, it is not valued & - \\
\hline $\begin{array}{l}\text { It has very little or no value because it has no significance for the criterion } \\
\text { or because it did not begin to achieve its goal }\end{array}$ & 0 \\
\hline $\begin{array}{l}\text { When applicable: it has little value because it has very little significance } \\
\text { for the criterion or because it barely begins to reach its objective. } \\
\text { Intermediate value between zero and medium interest }\end{array}$ & 2 \\
\hline $\begin{array}{l}\text { It has medium value because it is moderately significant for the criterion } \\
\text { or because it reaches only half of its objective }\end{array}$ & 2 \\
\hline $\begin{array}{l}\text { When applicable: it has sufficient value to be of significant importance for the } \\
\text { criterion or it nearly meets its objective. Between medium value and high value }\end{array}$ & 3 \\
\hline $\begin{array}{l}\text { It is highly valuable because it has a lot of interest for the criterion or it meets } \\
\text { its objective }\end{array}$ & 4 \\
\hline
\end{tabular}

Depending on the nature of the criterion, a scale of three levels of values - 0, 2 and 4 will suffice; for more complex criteria, which admit more nuances, a more detailed scale of five levels may be used: in this case the intermediate values between 1 and 3 will be used.

The weighting $w_{i}$ or importance given to each criterion $y_{i}$ is established based on two principles previously set out:

- 1. Since our legal framework establishes that the three aspects are to be taken into account - technical, social and economic aspects - without preponderance of one over another, each of them must weigh the same in the final decision.

$$
\sum_{i} w_{i}^{T e c}=\sum_{i} w_{i}^{S o c}=\sum_{i} w_{i}^{E c}=0.333 \text {. }
$$

- 2. Once established which criteria are to be used, in general conditions it is proposed that within their group all of them have the same weight. This way, the weight of each group of criteria would be the result expressed in Table 2 . 
Table 2. $W_{i}$ weighting for each group of criteria (source: own development)

\begin{tabular}{|c|c|c|}
\hline Group of criteria & No. of criteria per group ${ }^{*}$ & Weighted $w_{i}$ for each criterion \\
\hline Technical & $n_{t}$ & $0.333 / n_{t}$ \\
\hline Social & $n_{s}$ & $0.333 / n_{s}$ \\
\hline Economic & $n_{e}$ & $0.333 / n_{e}$ \\
\hline
\end{tabular}

Note: ${ }^{*} n_{t}+n_{s}+n_{e}=n$.

Once the particular conditions of each criterion have been analyzed, the $w_{j}$ weights can be justifiably modified according to each decision maker's opinion, so each evaluation may be open to a wide range of definitions. Both the assignment of the rating $r_{i j}$ and the assigned weights $w_{i}$ will be decisive in the multi-criteria evaluation.

The data obtained via the application of the method are expressed in the evaluation matrix, where we can analyze and compare the values assigned to each of the alternatives. The matrix scheme can be manifested as follows:

\begin{tabular}{|c|c|c|c|c|}
\hline & & Alternative $x_{1}$ & Alternative $x_{2}$ & $\cdots \quad$ Alternative \\
\hline Criterion & $y_{1}$ & $w_{1}^{*} r_{11}$ & $w_{1}{ }^{*} r_{12}$ & $w_{1}^{\star} r_{1 m}$ \\
\hline Crit & $y_{2}$ & $w_{2}{ }^{*} r_{21}$ & $w_{2}{ }^{\star} r_{22}$ & $w_{2}{ }^{\star} r_{2 m}$ \\
\hline$\ldots$ & & & & $\cdots$ \\
\hline iterion & $y_{n}$ & $w_{n}{ }^{*} r_{n 1}$ & $w_{n}{ }^{*} r_{n 2}$ & $w_{n}{ }^{\star} r_{n m}$ \\
\hline
\end{tabular}

The score obtained by each alternative by group of criteria -technical, social and economic- is reflected as follows:

$$
\begin{aligned}
& \text { Alternative } x_{1} \quad \text { Alternative } x_{2} \quad \cdots \quad \text { Alternative } x_{m} \\
& \text { Score } S_{1}^{T e c}=\sum_{i} w_{i}{ }^{*} r_{i 1} \quad S_{2}^{T e c}=\sum_{i} w_{i}{ }^{*} r_{i 2} \quad \cdots \quad S_{m}^{T e c}=\sum_{i} w_{i}{ }^{*} r_{i m} \\
& \text { by } S_{1}^{S o c}=\sum_{i} w_{i}{ }^{*} r_{i 1} \quad S_{2}^{S o c}=\sum_{i} w_{i}{ }^{*} r_{i 2} \quad \cdots \quad S_{m}^{S o c}=\sum_{i} w_{i}{ }^{*} r_{i m} \cdot \\
& \text { group } S_{1}^{E c}=\sum_{i} w_{i}{ }^{*} r_{i 1} \quad S_{2}^{E c}=\sum_{i} w_{i}^{*} r_{i 2} \quad \cdots \quad S_{m}^{E c}=\sum_{i} w_{i}{ }^{*} r_{i m}
\end{aligned}
$$

Lastly, the total score obtained by each alternative is reflected as follows:

$$
\begin{aligned}
& \text { Alternative } x_{1} \text { Alternative } x_{2} \cdots \text { Alternative } x_{m}
\end{aligned}
$$

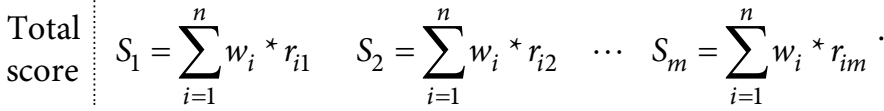

With the Scoring method as a proposed multi-criteria valuation method, we finally obtain a list of $m$ ordered alternatives in order, from the highest to lowest by the numerical rating $S_{j}$ obtained by each one of them.

At a first reading of the results, the highest score obtained should be considered the best solution. However, the establishment of reasonable accommodation must imply not only the achievement of the highest score within the evaluation process, but also the achievement of a certain balance between the adopted criteria. Therefore, an alternative $x_{j}$ will be considered as reasonable accommodation if it reaches at least $50 \%$ of the score within the group of criteria. This condition is reflected in the Equation 2. 


$$
x_{j} \text { reasonable accommodation if }\left\{\begin{array}{l}
\sum_{j=1}^{n_{t}} S_{j}^{T e c} \geq 0,5\left(\max \sum_{j=1}^{n_{t}} S_{j}^{T e c}\right) \\
\sum_{j=1}^{n_{s}} S_{j}^{S o c} \geq 0,5\left(\max \sum_{j=1}^{n_{s}} S_{j}^{S o c}\right) \ldots . \\
\sum_{j=1}^{n_{e}} S_{j}^{E c o} \geq 0,5\left(\max \sum_{j=1}^{n_{e}} S_{j}^{E c o}\right.
\end{array}\right)
$$

\section{Selection of decision criteria}

The decision criteria constitute the points of view or parameters that are used to express the decision maker's preferences. They are the reference elements on the basis of which the decision is made (Garcia-Cascales et al., 2009).

In most multi-criteria decision problems it is difficult to establish these decision criteria. However, their determination is an essential step in the process. The concept of criteria encompasses the concepts of "goal", "attribute" and "objective" (Romero, 1993):

- An objective indicates in which direction the decision-making unit should strive to do things better.

- The attributes are the characteristics that define the alternatives and measure the degree of scope or fulfilment of an objective. For each alternative, attributes that will allow the determination of a consequence for a decision in relation to the decision-maker's preference system are established. Attributes always provide the decision maker with values with regards to an objective reality and can be expressed through a mathematical function of decision variables, so that each alternative can be characterized by a set of measures related to the decision maker's objectives. They must meet two conditions: they must be measured with independence of the decision maker's interests and must be expressed as a function of the corresponding decision variables.

- A goal is defined as the value that quantifies an acceptable level of achievement that an attribute must strive to achieve.

The criteria chosen as references to manifest the preferences of the decision maker in terms of accessibility in housing are classified into three groups, which can be subdivided into a series of subgroups according to the homogeneity of the nature of the same.

In Table 3 the structure of groups and subgroups of criteria that will be used in the decision making is reflected.

The selected criteria, in addition to being considered necessary in the decision making process, are criteria with a value that can be compiled, either because it is based on public information, or because the final addressee can provide this data. Criteria that could be useful but proves to be unobtainable, for example, the level of income of the users of the building in the case where the building is under the system of Horizontal Property with a resident's association, must be discarded.

Some criteria, and after deeper analysis into the number and nature of those to be used, have been considered to have a specific and superior weight due to their greater relevance. 
Table 3. Criteria: groups and subgroups (source: own development)

\begin{tabular}{|c|c|c|}
\hline $\begin{array}{l}\text { Group of } \\
\text { criteria }\end{array}$ & Subgroups of criteria & Criteria \\
\hline \multirow{15}{*}{$\begin{array}{l}\text { Technical } \\
\left(n_{t}\right)\end{array}$} & \multirow{8}{*}{$\begin{array}{l}\text { Satisfaction of needs } \\
\text { of persons with } \\
\text { disabilities } \\
\text { (65\%s/technical) }\end{array}$} & Level of accessibility of the 'design for all' proposal \\
\hline & & Level of accessibility of the proposal for mobility \\
\hline & & Level of accessibility of the hearing proposal \\
\hline & & Level of accessibility of the proposal for vision \\
\hline & & Increase in level of accessibility design for all \\
\hline & & Increase level of accessibility - mobility \\
\hline & & Increase level accessibility - hearing \\
\hline & & Increase level accessibility - vision \\
\hline & \multirow{4}{*}{$\begin{array}{l}\text { Building's } \\
\text { technological } \\
\text { conditions }\end{array}$} & Architectural design \\
\hline & & Physical status \\
\hline & & Uses and activities \\
\hline & & Relations with the environment \\
\hline & \multirow{3}{*}{ Regulatory framework } & Technical \\
\hline & & Urban \\
\hline & & Administrative \\
\hline \multirow{7}{*}{$\begin{array}{l}\text { Social } \\
\left(n_{s}\right)\end{array}$} & \multirow{3}{*}{$\begin{array}{l}\text { Persons' functional } \\
\text { diversity } \\
\text { (65\% s/social) }\end{array}$} & Number of persons with disabilities \\
\hline & & Type of disability \\
\hline & & Number of elderly people \\
\hline & \multirow{3}{*}{$\begin{array}{l}\text { Building's occupation } \\
\text { situation }\end{array}$} & Number of dependent persons \\
\hline & & Number of users of the building and number of floors \\
\hline & & Number of vacant apartments \\
\hline & Other situations & Risk of social exclusion, gender violence, etc. \\
\hline \multirow{8}{*}{$\begin{array}{l}\text { Economic } \\
\left(n_{e}\right)\end{array}$} & \multirow[b]{2}{*}{ Economic evaluations } & Cost of the measures (euros/year) \\
\hline & & $\begin{array}{l}\text { Reasonable accommodation, according to the Land Law } \\
\text { (50\%s/economic) }\end{array}$ \\
\hline & \multirow{2}{*}{$\begin{array}{l}\text { People's and } \\
\text { institutions' financial } \\
\text { capacity }\end{array}$} & $\begin{array}{l}\text { Income level of those with functional diversity/Income level } \\
\text { of the co-living units }\end{array}$ \\
\hline & & Annual budget of the residents' association \\
\hline & \multirow{2}{*}{ Improvement enablers } & Aid/Grants \\
\hline & & Possibility of funding \\
\hline & $\begin{array}{l}\text { Limit of the legal duty } \\
\text { of conservation }\end{array}$ & Replacement value \\
\hline & Other & $\begin{array}{l}\text { Other interventions (non-related to accessibility) planned } \\
\text { for the building }\end{array}$ \\
\hline
\end{tabular}

This is the case of the degree of satisfaction of the needs of persons with disabilities in the group of technical criteria; of the real situation of the users of the analysed building to whom the proposed alternatives are addressed, identified in the subgroup of criteria "functional diversity of people", within the group of social criteria; and the criterion of reasonable accommodation currently established by legislation, in the group of economic criteria. 
It should be noted that, regarding the choice of technical criteria that define the satisfaction of the needs of the persons with disabilities, two major groups have been differentiated:

1. The "design for all" group, whose principles should constitute the achievement of the "ideal situation" with regards to any action in the physical environment of buildings. This interest is understandable in light of the ageing population and social changes that are raising awareness about diversity and the need for inclusion of PWD, to guarantee their rights and their participation in society (Heylighen et al., 2017).

2. The group of specific needs required in three types of disability: mobile, visual and hearing. The objective pursued with this differentiation is to enable the determination of reasonable accommodation in an existing building with measures that may be especially useful for these people, as users of the analysed building (del Moral \& Delgado, 2010). These criteria will be incorporated into the multi-criteria evaluation proposed in those cases where people with these disabilities live in the analysed building. This prevents the intervention from becoming a disproportionate burden, as well as allowing it to be sufficiently close to the "ideal situation".

\section{Quantification of the selected criteria}

\subsection{Technical criteria}

The needs of the persons with disabilities are quantified based on the level of accessibility of each intervention proposal to improve accessibility. This is measured with percentages obtained using the SIG-ACCE tool.

The conditions of the building will also be taken into account when carrying out interventions to improve accessibility as well as the level of difficulty for their materialization from a legal standpoint.

The weighting of the satisfaction of disabled people (65\% out of the total of technical criteria) has been considered necessary over the remaining indicators of this group, given its relevance inside the group.

The ratings assigned in this group are those expressed in Table 4.

\subsection{Social criteria}

In contrast to technical and economic criteria, social criteria may be the more difficult to determine as aspects related to people and the circumstances in which they live must be quantified.

As is recognized in the Explanatory Memorandum of the Law on the Promotion of Personal Autonomy and Support for Persons in a Dependent Situation (Ley 39, 2006), the challenge is none other than to meet the needs of those people who, being in a situation of special vulnerability, require support in order to carry out essential activities of daily life, achieve greater personal autonomy and be able to fully exercise their rights of citizenship.

With the election of the social criteria, the discriminatory effects that the non-adoption of the proposed measures may imply for people with disabilities may be assessed. 
Table 4. Rating assigned to technical criteria (source: own development)

\begin{tabular}{|c|c|c|c|c|c|c|c|}
\hline $\begin{array}{l}\text { Subgroup } \\
\text { of criteria }\end{array}$ & Criteria & $R=0$ & $R=1$ & $R=2$ & $R=3$ & $R=4$ & Quantification \\
\hline \multirow{8}{*}{ 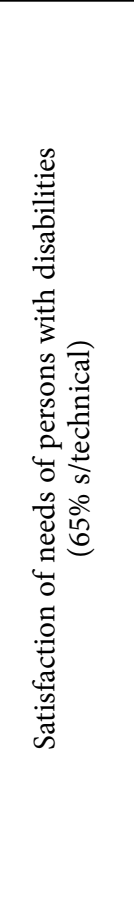 } & $\begin{array}{l}\text { Level of accessibility } \\
\text { of the 'design for all' } \\
\text { proposal }\end{array}$ & $<59$ & $\begin{array}{l}\text { From } 60 \\
\text { to } 69\end{array}$ & $\begin{array}{l}\text { From } 70 \\
\text { to } 79\end{array}$ & $\begin{array}{c}\text { From } 80 \\
\text { to } 89\end{array}$ & $\begin{array}{l}\text { From } 90 \\
\text { to } 100\end{array}$ & \multirow{4}{*}{$\begin{array}{c}>>\text { Level } \\
\text { of accessibility } \\
\text { obtained } \\
\text { through } \\
\text { alternative } \\
\equiv>>R\end{array}$} \\
\hline & $\begin{array}{l}\text { Level of accessibility } \\
\text { of the proposal for } \\
\text { mobility }\end{array}$ & $<59$ & $\begin{array}{l}\text { From } 60 \\
\text { to } 69\end{array}$ & $\begin{array}{l}\text { From } 70 \\
\text { to } 79\end{array}$ & $\begin{array}{l}\text { From } 80 \\
\text { to } 89\end{array}$ & $\begin{array}{c}\text { From } 90 \\
\text { to } 100\end{array}$ & \\
\hline & $\begin{array}{l}\text { Level of accessibility } \\
\text { of the hearing } \\
\text { proposal }\end{array}$ & $<59$ & $\begin{array}{l}\text { From } 60 \\
\text { to } 69\end{array}$ & $\begin{array}{c}\text { From } 70 \\
\text { to } 79\end{array}$ & $\begin{array}{l}\text { From } 80 \\
\text { to } 89\end{array}$ & $\begin{array}{c}\text { From } 90 \\
\text { to } 100\end{array}$ & \\
\hline & $\begin{array}{l}\text { Level of accessibility } \\
\text { of the proposal for } \\
\text { vision }\end{array}$ & $<59$ & $\begin{array}{l}\text { From } 60 \\
\text { to } 69\end{array}$ & $\begin{array}{l}\text { From } 70 \\
\text { to } 79\end{array}$ & $\begin{array}{l}\text { From } 80 \\
\text { to } 89\end{array}$ & $\begin{array}{c}\text { From } 90 \\
\text { to } 100\end{array}$ & \\
\hline & $\begin{array}{l}\text { Increase in level of } \\
\text { accessibility design } \\
\text { for all }\end{array}$ & $<5$ & $\begin{array}{l}\text { From } 5 \\
\text { to } 9\end{array}$ & $\begin{array}{l}\text { From } 10 \\
\text { to } 14\end{array}$ & $\begin{array}{l}\text { From } 15 \\
\text { to } 19\end{array}$ & $\geq 20$ & \multirow{4}{*}{$\begin{array}{c}>>\Delta \\
\text { accessibility } \\
\text { obtained } \\
\text { through } \\
\text { alternative } \\
\equiv>>\mathrm{R}\end{array}$} \\
\hline & $\begin{array}{l}\begin{array}{l}\text { Increase level of } \\
\text { accessibility - } \\
\text { mobility }\end{array} \\
\end{array}$ & $<5$ & $\begin{array}{l}\text { From } 5 \\
\text { to } 9\end{array}$ & $\begin{array}{l}\text { From } 10 \\
\text { to } 14\end{array}$ & $\begin{array}{l}\text { From } 15 \\
\text { to } 19\end{array}$ & $\geq 20$ & \\
\hline & $\begin{array}{l}\text { Increase level of } \\
\text { accessibility - } \\
\text { hearing }\end{array}$ & $<5$ & $\begin{array}{l}\text { From } 5 \\
\text { to } 9\end{array}$ & $\begin{array}{l}\text { From } 10 \\
\text { to } 14\end{array}$ & $\begin{array}{l}\text { From } 15 \\
\text { to } 19\end{array}$ & $\geq 20$ & \\
\hline & $\begin{array}{l}\text { Increase level of } \\
\text { accessibility - vision }\end{array}$ & $<5$ & $\begin{array}{l}\text { From } 5 \\
\text { to } 9\end{array}$ & $\begin{array}{l}\text { From } 10 \\
\text { to } 14\end{array}$ & $\begin{array}{l}\text { From } 15 \\
\text { to } 19\end{array}$ & $\geq 20$ & \\
\hline \multirow{4}{*}{ 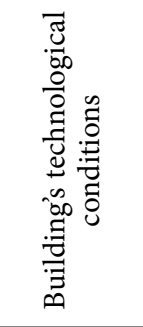 } & Architectural design & High & & Medium & & $\begin{array}{l}\text { Little or } \\
\text { void }\end{array}$ & \multirow{4}{*}{$\begin{array}{l}\text { Negative } \\
\text { influence }\end{array}$} \\
\hline & Physical status & High & & Medium & & $\begin{array}{l}\text { Little or } \\
\text { void }\end{array}$ & \\
\hline & Uses and activities & High & & Medium & & $\begin{array}{l}\text { Little or } \\
\text { void }\end{array}$ & \\
\hline & $\begin{array}{l}\text { Relations with the } \\
\text { environment }\end{array}$ & High & & Medium & & $\begin{array}{l}\text { Little or } \\
\text { void }\end{array}$ & \\
\hline \multirow{3}{*}{ 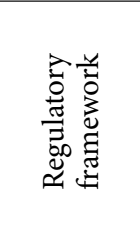 } & Technical & High & & Medium & & $\begin{array}{l}\text { Little or } \\
\text { void }\end{array}$ & \multirow{3}{*}{$\begin{array}{c}\text { Difficulty } \\
\text { with imple- } \\
\text { mentation }\end{array}$} \\
\hline & Urban & High & & Medium & & $\begin{array}{l}\text { Little or } \\
\text { void }\end{array}$ & \\
\hline & Administrative & High & & Medium & & $\begin{array}{l}\text { Little or } \\
\text { void }\end{array}$ & \\
\hline
\end{tabular}

Within a group of social criteria, functional diversity criteria are considered to best represent the social reality of the building. For that reason, they are $65 \%$ of the total value of the social criteria group.

The range of values has been established based on known statistical data:

- Number of persons with disabilities: the highest score is assigned to the situation which reflects a higher than national average number of persons with disabili- 
ties $-8.5 \%$ - (Instituto Nacional de Estadística [INE], 2008), with an average score being assigned to a situation similar to the national average;

- Number of elderly people: the highest score is assigned to that situation which reflects a higher than the national average number of elderly people $-16 \%$, according to the 2014 population pyramid - (INE, 2008);

- Number of dependent persons: the highest score is assigned to the situation that reflects a number of dependent persons higher than the average in Andalusia - 5.56\%. This indicator has been eliminated from the most relevant group for two reasons:

1. The objective of reasonable accommodation is universal accessibility, which can be understood as a principle that guarantees users the right to use the surrounding areas on equal terms, safely and in the most autonomous way possible. The dependent person, by definition, is unable to use them autonomously;

2. The statistics available related to dependent persons does not exclude persons with disabilities or the elderly, therefore, we know that this indicator is practically redundant if we take into account the other two;

- Number of persons using the building plus the number of floors: the number of people was obtained using the average occupancy of homes in Andalusia -2.4 room/ dwelling - (Orden de 29 de septiembre, 2008). This data are combined with the following requirement: in Andalusia a building is required to have an elevator if there are more than 17 homes / 2 floors, or more than 3 floors in any other case, according to the Accessibility Regulation of Andalusia (Decreto 293, 2009);

- Number of vacant apartments. Andalusia's current dwelling occupation situation is as follows: $17 \%$ vacant dwellings, $15 \%$ secondary homes and $68 \%$ of main homes (Ministerio de Fomento/Instituto Juan de Herrera, 2013).

The ratings assigned in this group are those expressed in Table 5.

\subsection{Economic criteria}

The group of economic criteria includes all of those criteria that have the euro as a fundamental unit of measurement.

The values for the range of criteria have been established based on available statistical data:

- The level of income of persons with functional diversity -or of the co-living units (icl)- for whom improvements in accessibility are being studied. The values of each of the ranges have been adopted according to the limits established by the Housing Plans approved in Andalusia for each of the programs established therein, from the infra-housing programs in the lower limit, to the housing programs of general public protection and private promotion, in the upper limit. The Multiple Income Public Income Indicator (RISB) has been used for this purpose;

- For the evaluation of the economic capacity of the institution that has to carry out the measure (the community of residence owners), some sections have been drawn up based on the regular annual budget of the community ( $a b)$, measured in $€ / d w e l l i n g$, with the purpose of having indicators in uniform units of measure which permit comparison. 
Table 5. Rating assigned to social criteria (source: own development)

\begin{tabular}{|c|c|c|c|c|c|c|c|}
\hline $\begin{array}{l}\text { Subgroup } \\
\text { of criteria }\end{array}$ & Criteria & $R=0$ & $R=1$ & $R=2$ & $R=3$ & $R=4$ & Quantification \\
\hline \multirow{3}{*}{ 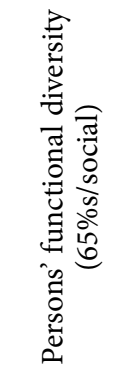 } & $\begin{array}{l}\text { Number } \\
\text { of persons } \\
\text { with disabilities } \\
\text { (pwd) }\end{array}$ & pwd $<5 \%$ & & $\begin{array}{c}5 \% \leq \text { pwd } \\
\leq 8.5 \%\end{array}$ & & pwd $>8.5 \%$ & \multirow{4}{*}{$>>$ No. $\equiv>>R$} \\
\hline & $\begin{array}{l}\text { Type of } \\
\text { disability } \\
\text { (not assessed) }\end{array}$ & & & & & & \\
\hline & $\begin{array}{l}\text { Number } \\
\text { of elderly people } \\
\text { (ep) }\end{array}$ & ep $<10 \%$ & & $\begin{array}{c}10 \% \leq \mathrm{ep} \\
\leq 16 \%\end{array}$ & & ep $>16 \%$ & \\
\hline \multirow{3}{*}{ 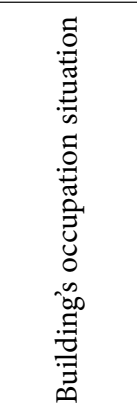 } & $\begin{array}{l}\text { Number of } \\
\text { dependent } \\
\text { persons }(\mathrm{dp})\end{array}$ & $\mathrm{dp}<5 \%$ & & $\begin{array}{c}5 \% \leq \mathrm{dp} \leq \\
10 \%\end{array}$ & & $\mathrm{dp}>10 \%$ & \\
\hline & $\begin{array}{l}\text { Number of } \\
\text { users of the } \\
\text { building (ub) } \\
\text { and number } \\
\text { of floors (nf) }\end{array}$ & $\begin{array}{c}\mathrm{ub}<17 \\
\text { and } \\
\mathrm{nf} \leq 2\end{array}$ & & $\begin{array}{c}\mathrm{ub} \geq 17 \\
\text { and } \mathrm{nf}=2\end{array}$ & & $\mathrm{nf} \geq 3$ & $\begin{array}{c}>>\text { No. } \equiv>>\mathrm{R} \\
(>>\text { recipients }) \\
>>\text { no. of floors } \\
\equiv>>\mathrm{R}\end{array}$ \\
\hline & $\begin{array}{l}\text { Number } \\
\text { of vacant } \\
\text { apartments (v) }\end{array}$ & $v \geq 32 \%$ & & $\begin{array}{c}32 \%>v \geq \\
17 \%\end{array}$ & & $\mathrm{v}<17 \%$ & $>>$ No. $\equiv<<$ R \\
\hline 壳递 & $\begin{array}{l}\text { Risk of social } \\
\text { exclusion, } \\
\text { gender violence, } \\
\text { etc. }\end{array}$ & $\begin{array}{l}\text { No } \\
\text { people in } \\
\text { social ex } \\
\text { risk }\end{array}$ & & $\begin{array}{l}\text { One } \\
\text { person in } \\
\text { situation } \\
\text { of risk }\end{array}$ & & $\begin{array}{l}\text { More than } \\
\text { one person } \\
\text { in situation } \\
\text { of risk or in } \\
\text { situation of } \\
\text { multiple risk }\end{array}$ & $\begin{array}{c}\text { >>Value } \\
\text { >>situation } \\
\text { of risk }\end{array}$ \\
\hline
\end{tabular}

The values of the considered annuities, according to the survey data, go from budgets of less than $€ 120$ / dwelling (equivalent to $€ 10$ / month per dwelling) for the section of lower economic capacity, up to budgets of above $€ 1,020$ / dwelling (equivalent to $€ 85$ / month per dwelling) for the section with the greatest economic capacity.

- The scoring sections of the costs of the measure $(\mathrm{cm})$ have been established according to the sections defined for the amounts of the aid (ag), assigning an inversely proportionate score in each case:

- The higher the measure expenses, the lower the rating;

- The higher the aid likely to be received, the higher the rating.

- The relationship between the costs of the measures $(\mathrm{cm})$ and the aids (ag), are established by the limits of the aids (ag) under the current State Housing Plan (Real Decreto 233, 2013), assumed by Andalusia in the Order for the promotion of building renovations (Orden de 28 de abril, 2015). The limit is $50 \%$ of the cost of the intervention and 10,000€ / dwelling (€ 14,000 / dwelling as the limit of aid (ag) in terms of accessibility if it requires structural intervention). Aids that reach $75 \%$ of the budget of the intervention have been endowed with the maximum score of 4 , in accordance 
with the Order of rehabilitation of buildings entrusted to the Public Land Company of Andalusia (Orden de 9 de Agosto, 2005).

- Reasonable accommodation according to (Real Decreto Legislativo 7, 2015). In the section of the economic valuations, within the group of economic indicators, the criterion legally established by the Land Law for the consideration of reasonable accommodation must be given greater relevance than the others. In this case, $50 \%$ of the weight has been assigned within the set of economic criteria. The intention is to adjust the results obtained through the proposed method to the current legal framework as much as possible, with regards to the objectives set out in this research project.

- Aids or grants (ag) that can be obtained in order to carry out the alternatives. These subsidies can be those included in the current State Plan for Building Rehabilitation 2013-2016 (Real Decreto 233, 2013), in the Housing Plans of the Autonomous Communities, in the Municipal Programs for assistance in the rehabilitation and elimination of architectural barriers, etc.

- Funding possibilities (f). A financial study that evaluates the possibility of obtaining a loan to execute the planned works, which allows the amortization of the cost of these works in a reasonable period of time, is necessary. In the most complex case regarding a resident's association, each financial institution establishes the conditions under which this type of credit would be subject to concession, as the resident's association has legal incapacity to act in this sense. Consulted some financial entities, they require the unanimous approval of the extraordinary budget in order to execute these works, and that the administrator is a professional collegiate, as a guarantee of the validity of the procedures and administrative procedures necessary (notifications, counting of votes, period of contestation of agreements, etc.)

- Net replacement value (rv), or value of the building in its current state, including depreciation according to its age and conservation. This value can be obtained from the cadastral values; failing this, the value can be obtained from the applicants' property tax receipt, extrapolating this value to the rest of the building. This value is decisive when establishing the legal limit for the conservation of a building.

- Other planned interventions in the building. This can be positive as they can provide an opportunity to eliminate barriers. But it can also be a negative factor as it may lead to an increase in the final cost of the work on the building. Information about these other interventions is required, as well as the budget for them.

The ratings assigned in this group are those expressed in Table 6.

\section{Discussion of research incomes}

The main objective of this article is to formulate a proposal for evaluating interventions that can be undertaken in a multi-family residential building to improve accessibility. In addition, this evaluation proposal makes it possible to determine if those interventions can be considered reasonable accommodation, as required by current legislation on equal rights for persons with disabilities. 


\begin{tabular}{|c|c|c|c|c|c|c|c|c|}
\hline 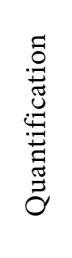 & 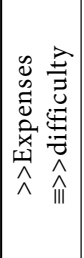 & 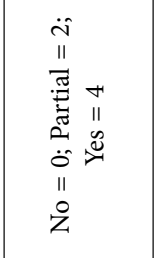 & 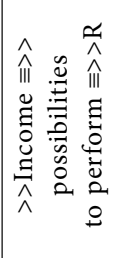 & 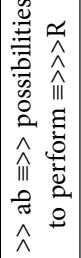 & 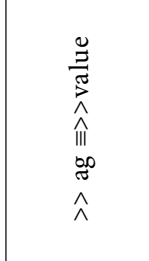 & 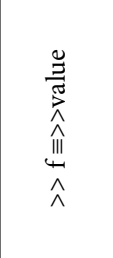 & & 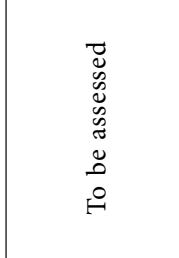 \\
\hline 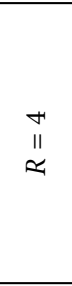 & $\begin{array}{l}8 \\
8 \\
i \\
\text { vi } \\
\text { g }\end{array}$ & 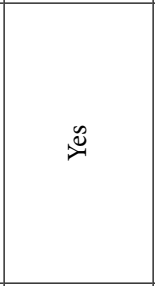 & 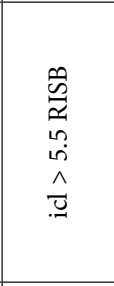 & $\begin{array}{l}\stackrel{\overbrace{}}{0} \\
\hat{-} \\
\hat{\sigma}\end{array}$ & 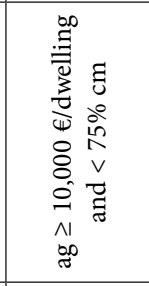 & 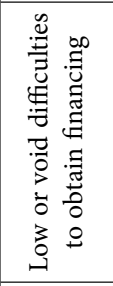 & 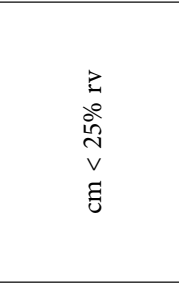 & 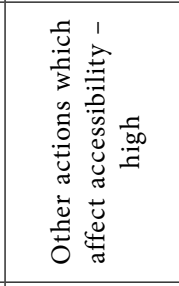 \\
\hline $\begin{array}{l}m \\
\approx \\
\approx\end{array}$ & $\left|\begin{array}{ll|}v & \\
E & \\
y & o \\
v 1 & 0 \\
o & i \\
0 & i \\
\infty & \end{array}\right|$ & & 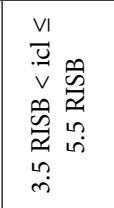 & 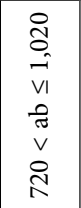 & 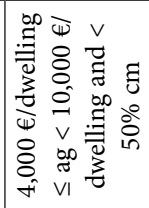 & & & \\
\hline$\underset{\sim}{N}$ & 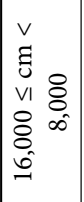 & 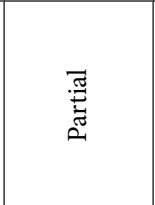 & 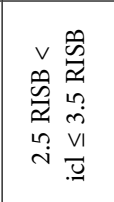 & 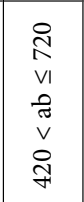 & 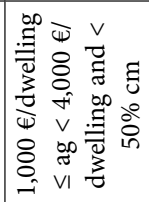 & 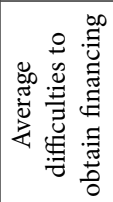 & 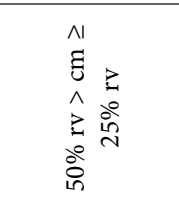 & 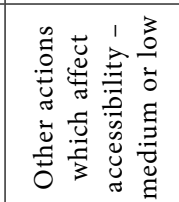 \\
\hline$\underset{\approx}{\overparen{a}}$ & 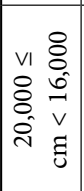 & & 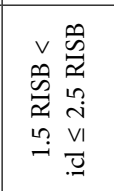 & 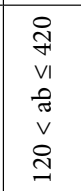 & 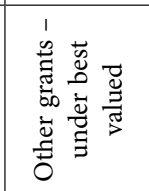 & & & \\
\hline $\begin{array}{l}0 \\
\| \\
\approx\end{array}$ & 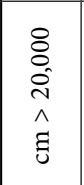 & ż & 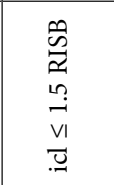 & $\begin{array}{l}\stackrel{\text { I }}{\mathrm{V}} \\
\mathrm{VI} \\
\text { ते }\end{array}$ & 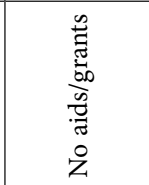 & $\begin{array}{l}\stackrel{0}{0} \\
\stackrel{0}{0} \\
0 \\
0 \\
0 \\
\stackrel{2}{0} \\
\stackrel{0}{z}\end{array}$ & $\begin{array}{l}3 \\
\geq \\
o \\
0 \\
\text { in } \\
\wedge 1 \\
\vdots \\
0\end{array}$ & 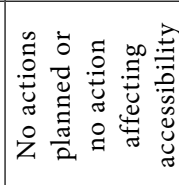 \\
\hline 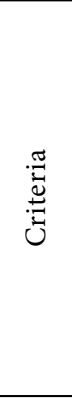 & 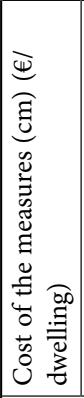 & 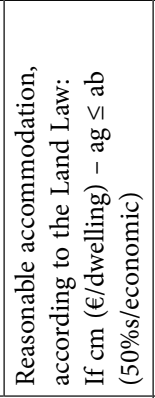 & 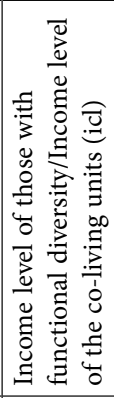 & 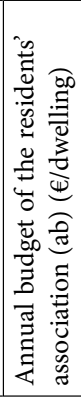 & 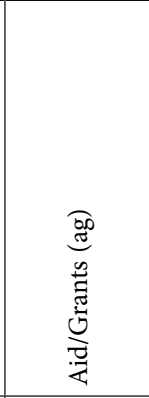 & 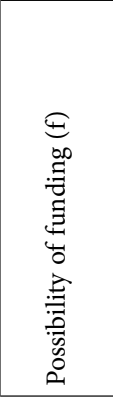 & 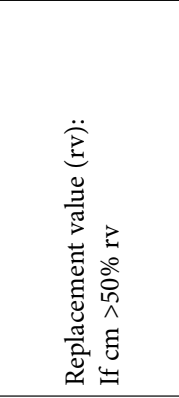 & 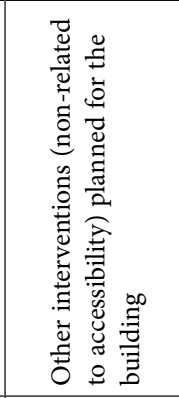 \\
\hline 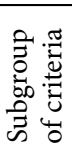 & \multicolumn{2}{|c|}{ 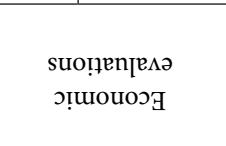 } & \multicolumn{2}{|c|}{ 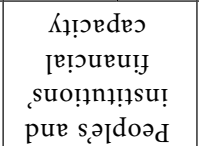 } & \multicolumn{2}{|c|}{ 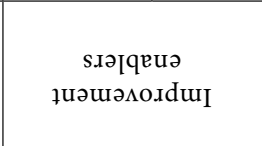 } & 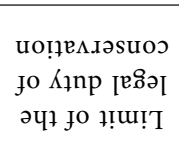 & Јә૫ҢО \\
\hline
\end{tabular}


This proposal is based on a fuzzy multi-criteria evaluation of technical, social and economic criteria (Delgado et al., 2016), using the Scoring method (Mardani et al., 2015) or linear weighting. In general, the person who must make a decision regarding a set of possible alternatives as a solution to a particular problem, does not tend to order them under a single criterion, which would greatly simplify the process. In fact, he/she does so by addressing a broad set of criteria which seems more appropriate. The proposal of alternatives is the responsibility of the intervening technician, and their adaptation of the alternatives to each situation will depend on their training and degree of specialization - whether or not the alternative is technically, urban and legally viable; whether or not the collection of data of the building and the social reality described has been carried out with rigour; or whether or not the proposed economic evaluations are correct.

The proposed methodology supposes a great scientific contribution intended to improve the quality of life of persons with disabilities in the environment in which they carry out an important part of the activities of daily life: their own home. There are four reasons for this scientific contribution:

- The determination of the fuzzy criteria of the linear weighting method used, consisting of three types of criteria: technical, social and economic. The current legislation only takes into account economic "cost-solution" criteria based on regular annual budgets of residents' associations in residential buildings.

- The quantification of the diffuse criteria responds to a scale of assessment of indicators that represent the reality in a quantitative, simple and direct way in order to allow a comparison between possible alternatives.

- The order of relevance of the alternatives based on the higher or lower score obtained expresses the greater or lesser adaptation to established diffuse criteria.

With this information it is possible to evaluate the degree to which the personal needs of persons with disabilities, with regards to the building where they live, are met. For this purpose, economic proportionality of those measures regarding the improvement of accessibility is taken into account, as well as the discriminatory effects that the non-adoption of these measures may entail.

\section{Conclusions}

By using the proposed method of diffuse multi-criteria evaluation, the two proposed objectives are reached:

1. A comparative evaluation of the possible alternatives available for the improvement of accessibility in residential buildings is proposed. It provides objective criteria to aid the decision of the best alternatives, which is important with regards to the decisionmaking process.

2. It is possible to determine reasonable accommodation according to corresponding legislative requirements, through a diffuse multi-criteria evaluation, calculated by the linear weighting method based on technical, social and economic criteria. The current determination of reasonable accommodation in residential buildings under the system of Horizontal Property has been greatly simplified by the definition of "disproportion- 
ate burden" in the Land and Rehabilitation Law (Real Decreto Legislativo 1, 2013). This norm establishes that the cost of the intervention must not exceed the value of a regular residents' association annuity. This measure does not highlight the complexity of the problem at hand nor does it meet the requirements of the Consolidated Text of the General Law on the Rights of Persons with Disabilities and their Social Inclusion (Real Decreto Legislativo 1, 2013). This means that we reduce all factors to monetary units exclusively as in the Operational Research era (Ríos et al., 1989), instead of proposing a more realistic approach to the explicit consideration of multiple criteria. This is the only way the problem of decision making can be properly addressed: through the construction of successive synthesis of objective criteria.

This linear weighting method and fuzzy logic are the ones that are used most frequently when decisions are made using multi-criteria evaluation techniques that have a spatial nature, which is why they can be implemented using Geographic Information Systems (GIS). In the case of the VIVable $\mathrm{R}+\mathrm{D}+\mathrm{i}$ project, this implementation is carried out through a WebApp prototype called SIG-ACCE.

The fuzzy multi-criteria evaluation method for the determination of reasonable accommodation proposed can be transposed (Guo \& Zhao, 2017; Mardani et al., 2015) to buildings of uses other than residential; technical, social and economic criteria would have to be adjusted to the requirements of the corresponding current legislation.

Lastly, the fuzzy multi-criteria evaluation method for the determination of the proposed reasonable accommodation can also be extrapolated to other countries as long as they are standardized in the basic requirements of accessibility in buildings, as well as in terms of equal rights for persons with disabilities. For this purpose, the technical, social and economic criteria established in the evaluation should be adjusted, as well as their quantification to the complex reality of the corresponding country.

\section{References}

Azcona, J. (2014, December). Modelo Fuzzy de determinación del valor unitario de edificación destinada a vivienda con fines catastrales. CT Catastro, 82, 7-34.

Cocco, F., \& Alonso, F. (2015). Ajustes razonables en la rehabilitación de polígonos de viviendas: aplicación al barrio Montserrat de Terrasa (Barcelona). ACE: Architecture, City and Environment, 10(29), 31-58. https://doi.org/10.5821/ace.10.29.3693

Council of Europe. (2000). Council Directive 2000/78/CE establishing a general framework for equal treatment in employment and occupation, L 303. Brussel: Official Journal of the European Communities.

de Oliveira, F. R., Garcia-Deitos, B., Dornelles, S., Azevedo, S. M., de Oliveira, M., \& Maciel, K. (2014). Barreras y facilitadores arquitectónicos: un desafío para la independencia funcional. Index de Enfermería, 23(3), 124-128. https://doi.org/10.4321/S1132-12962014000200002

Decreto 293. (2009). Decreto 293/2009, de 7 de julio, por el que se aprueba el Reglamento que regula las normas para la accesibilidad en las infraestructuras, el urbanismo, la edificación y el transporte en Andalucía. Consejería de la Presidencia de la Junta de Andalucía, Comunidad Autónoma de Andalucía: BOJA num. 219 de 10-11-2009. 
del Moral, C., \& Delgado, L. (2010). Metodología de la implementación de la accesibilidad en los entornos patrimoniales. Mexicali, Baja California, México: Universidad Autónoma de Baja California. Retrieved from http://hdl.handle.net/2099/12829

del Moral, C., \& Delgado, L. (2010). Evaluación de los niveles de accesibilidad en los entornos patrimoniales. ACE, Architecture, City and Environment, Especial, (13), 41-60.

Delgado, L., del Moral, C., Valverde-Espinosa, I., Gómez, A., Muñoz, J., Ortiz, D., Pavón, S., Sutil, M. A., \& Valverde-Palacios, I. (2015). Agencia de Obra Publica de la Junta de Andalucía. Retrieved 08 December 2017 from http://www.aopandalucia.es/innovacion/principal.asp?alias=Vivienda_accesible_sostenible

Delgado, L., del Moral, C., \& Corredor, E. (2016). Social Sustainability. The case study of "VIVable". Granada: Godel Impresiones Digitales, S. L. (pp. 1-5).

Garcia-Cascales, M., Lamata, M., \& Ruiz-Merino, R. (2009). Métodos para la comparación de alternativas mediante un Sistema de Ayuda a la Decisión (S.A.D.) y "Soft Computing". Retrieved 03 November 2014 from http://hdl.handle.net/10317/1022

Guo, S., \& Zhao, H. (2017). Fuzzy best-worst multi-criteria decision-making method and its applications. Knowledge-Based Systems, 121(1), 23-30. https://doi.org/10.1016/j.knosys.2017.01.010

Haque, A. N. (2016). Applications of Multi-Criteria Analysis on Climate Adaptation Assessment in the Context of Least Developed Countries. Journal of Multi-Criteria Decision Analysis, 23(5-6), 210-224. https://doi.org/10.1002/mcda.1571

Herrera, F., \& Herrera-Viedma, E. (2000). Linguistic decision analysis: steps for solving decision problems under linguistic information. Fuzzy Sets and Systems, 115(1), 67-82.

https://doi.org/10.1016/S0165-0114(99)00024-X

Herrera, F., Herrera-Viedma, E., \& Martínez, L. (2000). A fusion approach for managing multi-granularity linguistic term sets in decision making. Fuzzy Sets and Systems, 114(1), 43-58. https://doi.org/10.1016/S0165-0114(98)00093-1

Herrera, F., Herrera-Viedma, E., \& Verdegay, J. (1997). A rational consensus model in group decision making under linguistic assessment. Fuzzy Sets and Systems, 88(1), 31-49.

https://doi.org/10.1016/S0165-0114(96)00047-4

Herrera-Viedma, E., Martínez, L., Mata, F., \& Chiclana, F. (2005). A consensus support system model for group decision-making problems with multi-granular linguistic preference relations. IEEE Transactions on Fuzzy Systems, 13(5), 644-645. https://doi.org/10.1109/TFUZZ.2005.856561

Heylighen, A., Van der Linden, V., \& Van Steenwinkel, I. (2017). Ten questions concerning inclusive design of the built environment. Building and Environment, 114, 507-517. https://doi.org/10.1016/j.buildenv.2016.12.008

Instituto Nacional de Estadística [INE]. (2008). Encuesta de Discapacidad, Autonomía personal y situaciones de Dependencia (EDAD). Año 2008. Retrieved from http://www.ine.es/prensa/np524.pdf

Ji, P., Zhang, H., \& Wang, J. (2018). Selecting an outsourcing provider based on the combined MABAC-ELECTRE method using single-valued neutrosophic linguistic sets. Computers \& Industrial Engineering, 120, 429-441.

https://doi.org/10.1016/j.cie.2018.05.012

Kabir, G., Sadiq, R., \& Tesfamariam, S. (2014). A review of multi-criteria decision-making methods for infrastructure management. Structure and Infrastructure Engineering, 10(9), 1176-1210. https://doi.org/10.1080/15732479.2013.795978

Kahraman, C., Onar, S., \& Oztaysi, B. (2015). Fuzzy Multicriteria Decision-Making: A Literature Review. International Journal of Computational Intelligence Systems, 8(4), 637-666.

https://doi.org/10.1080/18756891.2015.1046325 
Kahraman, C., Suder, A., \& Cebi, S. (2013). Fuzzy multi-criteria and multi-experts evaluation of government investiments in higher education: the case of TurKey. Technological and Economic Development of Economy, 19(4), 549-569. https://doi.org/10.3846/20294913.2013.837110

Ley 39. (2006). Ley 39, de 14 de diciembre, de Promoción de la Autonomía Personal y Atención a las Personas en Situación de Dependencia. Madrid (Jefatura del Estado. Gobierno de España): BOE num. 299 de 15-12-2006.

Ley 51. (2003). Ley 51/2003, de 2 de diciembre, de Igualdad de Oportunidades, No Discriminación y Accesibilidad Universal de las Personas con Discapacidad (LIONDAU). Madrid (Presidencia del Gobierno de España): BOE num. 289 de 3-12-2003.

Liao, H., Xu, Z., \& Zeng, X. J. (2014). Distance and similarity measures for hesitant fuzzy linguistic term sets and their application in multi-criteria decision making. Information Sciences, 271, 125142. https://doi.org/10.1016/j.ins.2014.02.125

Liu, P. (2014). Some Hamacher Aggregation Operators Based on the Interval-Valued Intuitionistic Fuzzy Numbers and Their Application to Group Decision Making. IEEE Transactions on Fuzzy Systems, 22(1), 83-97. https://doi.org/10.1109/TFUZZ.2013.2248736

Mardani, A., Jusoh, A., \& Zavadskas, E. K. (2015). Fuzzy multiple criteria decision-making techniques and applications-Two decades review from 1994 to 2014. Expert Systems with Applications, 42(8), 4126-4148. https://doi.org/10.1016/j.eswa.2015.01.003

Ministerio de Fomento/Instituto Juan de Herrera. (2013). Análisis de las características de la edificación residencial en España. Retrieved from https://www.fomento.gob.es/areas-de-actividad/arquitecturavivienda-y-suelo/urbanismo-y-politica-de-suelo/observatorio-de-la-vulnerabilidad-urbana/analisis-de-las-caracteristicas-de-la-edificacion-residencial-en-espan\%CC\%83a

Morente-Molinera, J., Kou, G., González-Crespo, J. M., Corchado, J. M., \& Herrera-Viedma, E. (2017). Solving multi-criteria group decision problems under environments with a high number of alternatives using fuzzy ontologies and multi-granular linguistic modelling methods. Knowledge-Based Systems, 137, 54-64. https://doi.org/10.1016/j.knosys.2017.09.010

Oltean-Dumbrava, C., Watts, G., \& Miah, A. (2016). Towards a more sustainable surface transport infrastructure a case study of applying multicriteria analysis techniques to assess the sustainability of transport noise reducing devices. Journal of Cleaner Production, 112, 2922-2934.

https://doi.org/10.1016/j.jclepro.2015.09.096

Orden de 28 de abril. (2015). Por la que se aprueban las bases reguladoras para la concesión, en régimen de concurrencia competitiva, de subvenciones destinadas al fomento de la rehabilitación edificatoria en la Comunidad Autónoma de Andalucía, para el ejercicio 2015. Sevilla (Consejería de Fomento y Vivienda de la Junta de Andalucía, Comunidad Autónoma de Andalucía): BOJA num. 82 de 30-04-2015.

Orden de 29 de septiembre. (2008). Por la que se regula el coeficiente aplicable para el cálculo de crecimiento poblacional derivado de las viviendas previstas en los instrumentos de planeamiento urbanístico. Sevilla (Consejería de Vivienda y Ordenación del Territorio de la Junta de Andalucía, Comunidad Autónoma de Andalucía): BOJA num. 209 de 21-10-2008.

Orden de 9 de Agosto. (2005). Línea de actuación para la rehabilitación de edificios residenciales y la mejora de sus dotaciones e instalaciones, encomendada su ejecucicón a EPSA. Sevilla (Consejería de Obras Públicas y Transportes de la Junta de Andalucía, Comunidad Autónoma de Andalucía): BOJA num. 168 de 29-08-2005.

Pedrycz, W., Ekel, P., \& Parreiras, R. (2011). Fuzzy Multicriteria Decision-Making. Models, Methods and Applications. Chichester: s.n.

Real Decreto 233. (2013). Real Decreto 233/2013, de 5 de abril, por el que se regula el Plan Estatal de fomento del alquiler de viviendas, la rehabilitación edificatoria, y la regeneración y renovación urbanas, 2013-2016. Madrid (Ministerio de Fomento, Gobierno de España): BOE num. 86 de 10-04-2013. 
Real Decreto Legislativo 1. (2013). Real Decreto Legislativo 1/2013, de 29 de noviembre, por el que se aprueba el Texto Refundido de la Ley General de los Derechos de las Personas con Discapacidad y su Inclusión Social. Madrid (Ministerio de Sanidad, Servicios Sociales e Igualdad, Gobierno de España): BOE num. 289 de 3-12-2013.

Real Decreto Legislativo 7. (2015). Real Decreto Legislativo 7/2015, de 30 de octubre, por el que se aprueba el texto refundido de la Ley de Suelo y Rehabilitación Urbana. Madrid (Ministerio de Fomento. Gobierno de España): BOE num. 261 de 31-11-2015.

Ríos, S., Ríos-Insúa, S., \& Ríos-Insúa, M. (1989). Procesos de decisión multicriterio. Madrid: Edicicones de la Universidad Complutense, S.A. (EUDEMA, S.A.).

Romero, C. (1993). Teoría de la decisión multicriterio: conceptos, técnicas y aplicaciones. Madrid: Alianza Editorial S.A.

Suder, A., \& Kahraman, C. (2016). Multi-criteria analysis of technological innovation investiments using fuzzy sets. Technological and Economic Development of Economy, 22(2), 235-253. https://doi.org/10.3846/20294913.2014.994191

Tapia, J., Del Moral, J. M., Tapia, C., Martínez, M. A., \& Amor, R. (2012). A consensus model for group multicriteria decision making problems with interval fuzzy preference relations. Métodos Cuantitativos para la Economía y la Empresa. Diciembre, 36-53.

Tapia, J., Del Moral, M., Martínez, M., \& Herrera-Viedma, E. (2012). A consensus model for group decision making problems with linguistic interval fuzzy preference relations. Expert Systems with Applications, 39, 10022-10030.

https://doi.org/10.1016/j.eswa.2012.02.008

United Nations. (2006). Convention on the Rights of Persons with Disabilities, CRPD. (Resolution 61/106). New York: General Assembly.

Vitoriano, B. (2007). Teoría de la Decisión: Decisión con Incertidumbre, Decisión Multicriterio y Teoría de Juegos. Retrieved from http://www.mat.ucm.es/ bvitoria/Archivos/a_dt_UCM.pdf

Wang, J., Lu, P., Zhang, H., \& Chen, X. (2014). Method of multi-criteria group decision-making based on cloud aggregation operators with linguistic information. Information Sciences, 274, 177-191. https://doi.org/10.1016/j.ins.2014.02.130

Wang, L., Peng, J., \& Wang, J. (2018b). A multi-criteria decision-making framework for risk ranking of energy performance contracting project under picture fuzzy environment. Journal of Cleaner Production, 191, 105-118. https://doi.org/10.1016/j.jclepro.2018.04.169

Wang, X., Peng, H., \& Wang, J. (2018a.) Hesitant linguistic intuitionistic fuzzy sets and their application in multi-criteria decision-making problems. International Journal for Uncertainty Quantification, 8(4), 321-341. https://doi.org/10.1615/Int.J.UncertaintyQuantification.2018019996

Wei, C., Zhao, N., \& Tang, X. (2014). Operators and Comparisons of Hesitant Fuzzy Linguistic Term Sets. IEEE Transactions on Fuzzy Systems, 22(3), 575-585. https://doi.org/10.1109/TFUZZ.2013.2269144

$\mathrm{Xu}, \mathrm{Z}$. (2004). On compatibility of interval fuzzy preference relations. Fuzzy Optimization and Decision Making, 3(3), 217-225. https://doi.org/10.1023/B:FODM.0000036864.33950.1b

$\mathrm{Xu}, \mathrm{Z}$. (2005). An approach to group decision making based on incomplete linguistic preference relations. International Journal of Information Technology and Decision Making, 4(1), 153-160. https://doi.org/10.1142/S0219622005001349

$\mathrm{Xu}, \mathrm{Z}$. (2007). A survey of preference relations. International Journal of General Systems, 36(2), 179-203. https://doi.org/10.1080/03081070600913726

$\mathrm{Xu}, \mathrm{Z}$., \& Yager, R. (2009). Intuitionistic and interval-valued intuitionistic fuzzy preference relations and their measures of similarity for the evaluation of agreement within a group. Fuzzy Optimization and Decision Making, 8, 123-139. https://doi.org/10.1007/s10700-009-9056-3 
Yager, R. R. (2014). Pythagorean Membership Grades in Multicriteria Decision Making. IEEE Transactions on Fuzzy Systems, 22(4), 958-965. https://doi.org/10.1109/TFUZZ.2013.2278989

Zadeh, L. (1975a). The concept of a linguistic variable and its applications to approximate reasoning. Part I. Information Sciences, 8(3), 199-249. https://doi.org/10.1016/0020-0255(75)90036-5

Zadeh, L. (1975b). The concept of a linguistic variable and its applications to approximate reasoning. Part II. Information Sciences, 8(4), 301-357. https://doi.org/10.1016/0020-0255(75)90046-8

Zadeh, L. (1975c). The concept of a linguistic variable and its applications to approximate reasoning. Part III. Information Sciences, 9(1), 43-80. https://doi.org/10.1016/0020-0255(75)90017-1

Zhang, T., Wang, J., \& Zhang, H. (2018). An integrated approach for failure mode and effects analysis based on fuzzy best-worst, relative entropy, and VIKOR methods. Applied Soft Computing, 72, 636-646. https://doi.org/10.1016/j.asoc.2018.03.037

Zhang, X., Zhang, H., \& Wang, J. (2017). Discussing incomplete 2-tuple fuzzy linguistic preference relations in multi-granular linguistic MCGDM with unknown weight information. Soft Computing, 23(6), 2015-2032. https://doi.org/10.1007/s00500-017-2915-x

Zhu, B., \& Xu, Z. (2016). Extended hesitant fuzzy sets. Technological and Economic Development of Economy, 22(1), 100-121. https://doi.org/10.3846/20294913.2014.981882 